Отримано: 16 січня 2020 року

Прорецензовано: 23 січня 2020 року

Прийнято до друку: 29 січня 2020 року

e-mail: kpi.pavlovych@gmail.com

DOI: $10.25264 / 2519-2558-2020-9(77)-276-279$
Pavlovych A. V. Australian English and Canadian English as Two Examples of Language Development. Наукові записки Наиіонального університету «Острозька академія»: серія «Філологія». Острог: Вид-во НаУОА, 2020. Вип. 9(77). С. 276-279.

Andrii V. Pavlovych, National Technical University of Ukraine "Igor Sikorsky Kyiv Polytechnic Institue"

\title{
AUSTRALIAN ENGLISH AND CANADIAN ENGLISH AS TWO EXAMPLES OF LANGUAGE DEVELOPMENT
}

The article is devoted to the development of English in Australia and Canada. The analysis of historical, social and political prerequisites of formation of English in Australia and Canada has been conducted. The influence of extralinguistic factors on the development of English in the abovementioned countries, the universalization of vocabulary, grammar and phonetic structure of the language is described. The geographical location and lifestyle of Indigenous people and migrants had a significant impact on the development of Australian English. Concerning Canadian English, it should be mentioned that Canada is a bilingual country and French, and French, as well as American and British English, had a considerable influence on the development of language in this country.

Key words: Australia English, Canadian English, vocabulary, grammar, accent, phonetics, special features.

Павлович Андрій Васильович,

Національний технічний університет України «Київський політехнічний університет ім. Ігоря Сікорського»

\section{АВСТРАЛІЙСЬКА АНГЛІЙСЬКА ТА КАНАДСЬКА АНГЛІЙСЬКА ЯК ДВА ПРИКЛАДИ РОЗВИТКУ МОВИ}

Статтю присвячено розвитку англійської мови в Австралї та Канаді. Проведено аналіз історичних, сочіальних та політичних передумов становлення англійської мови в Австралії та Канаді. Описано вплив екстралінгвальних чинників на розвиток англійської мови у вище згаданих англомовних краӥнах, універсалізацію лексики, граматики та фонетичної структури мови. Значний вплив на розвиток австралійської англійської мови мали географічне положення та спосіб життя корінного населення та мігрантів. Що до розвитку англійської мови в Канаді, то варто відмітити, щзо Канада - це двомовна крайна і суттєвий вплив на розвиток мови в цій краӥні мала франиузька мова, так само як і американська та британська англійська.

Ключові слова: Австралійська англійська, канадська англійська, словниковий запас, граматика, акцент, фонетика, особливі характеристики.

The article is devoted to the development of the English language in Australia and Canada. Due to the number of historic events and social aspects Australian English and Canadian English acquired individual linguistic features. The purpose of this article is to study vocabulary, grammar and phonetics of AusE and CanE in terms of historical and social aspects.

It is important to mention that English was spoken on the British Isles before the British arrived in Australia. At the end of the eighteenth century one third of the British population spoke Celtic Languages. The English spoken in those times was far from what we call now Standard English. The first dictionary of English was published in 1755.

The first settlers from Britain were prisoners who arrived to colonies in New South Wales. Captain Cook arrived in Australia in 1770 and 20 years later the first colony was established. G. W Turner mentioned the process of a "consequent mixing, leveling and simplification of language" [1].

People with different accents were brought to Australia which is crucially important to take into consideration as Aboriginal language and these accents of English were the start of AusE. Many features were brought from England, Scotland and Ireland into AusE but those from London and Ireland caused a major influence [2].

The term Australian English originates from 1940 when it was first recorded. Previously it related to the colonial decline from Standard English. From the very beginning British colonies were penal and contact with indigenous population was at a very low level though a set of words was borrowed (boomerang, dingo, kangaroo, koala, kookaburra, wombat).

Vocabulary. As it has been mentioned above the first settlements were penal colonies which influenced AusE a lot as the vocabulary similar to the one of a slave society was in use among convicts. For instance the words bond and free (free native, free emigrant) had a considerable distinction. The words free and freed reflect an interesting historical aspect. Convicts who were released from prison when terms of their sentences were over or the convicts became emancipists (those who obtained pardons) were known as free convicts, freed men, exclusives or exclusionists. Though convicts after their imprisonment had a limited degree of freedom. On the other hand there were also military servants and free settlers which might have caused the phenomenon mentioned above.

Stock-raising gave the impetus to the enrichment of AusE vocabulary. Graziers or squatters were stock-raisers who moved inland from limits of location (the frontier of settlement) into the back country or back of beyond looking for land for runs (grazing land) or stations (ranches). Brush (dense natural vegetation), scrub (poor vegetation) were commonly used by such people. Overseers or superintendents (these are convict terms), stockmen and rouseabouts were employed in the industry. Drovers moved stock overland at long distances, original overlanders did the same travelling from New South Wale to South Australia. Sheep industry played a huge role in the development of frontier society and professional vocabulary of droving and shearing is widely used in Australian literature [3].

The distinctive feature of AusE lexicon is that it reflects attitudes, values and self-perception of Australians. The word mateship means a code of behaviour based on solidarity and fellowship between mates. Larrikin is a mischievous young person. Informality 
and irreverent humor are distinctive features of AusE. For instance, drunk as a skunk means very drunk and other ruder expressions clearly illustrate it. This vernacular trait in AusE originated from convicts and settlers from 1788. Rude language is a common thing in spoken AusE and these are males who use it more compared to females. Expressions to describe somebody`s appearance, mental ability or character features manifest a great linguistic creativity of Australians: lower than a snake 's belly (someone with low morals or something low), silly as a chook with its head cut off (with great haste, with careless manner). Another interesting feature of AusE is the use of rude language to those who they are affectionate to.

On the other hand there are expressions borrowed from American English such as cookie, guy, dude caused by communication changes and the influence of American culture. In general American English has influenced AusE only in terms of lexicon. There are words in which stress patterns are from American English (e. g. finANCE to FINance, research to REsearch). There is also emission of the in structures of the type I play (the) piano. It must be mentioned that many Aboriginal words are used actively as well, e. g. Uluru for Ayers Rock.

Pronunciation Received Pronunciation (RP) ("Queen`s English" or "BBC English") is one of the most prestigious accents. On the other hand the speech of AusE is not "linguistically uniform" and has a lot of varieties. For instance the vowels in lexical sets FLEECE, FACE, PRICE, GOOSE, GOAT, MOUTH are significant when accents of AusE are compared. There are many Irish features as well which was caused by immigration from Ireland.

There are three main varieties of AusE: Broad AusE, General AusE and Cultivated AusE. Broad appeared in New South Wales in 1830s. It has similar characteristics to the speech of London and southeast England. This is the accent of low social layers. General Australian became widespread between 1870 and 1890. It was formed in the environment of free settlers and prisoners. General was the considered new, urban and more prestigious compared to Broad. There was also certain mixture of these accents. Cultivated is the most similar to RP. The shift in pronunciation is the influence of RP. According to G. Leitner this accent related to education and many social clubs, formed in 1830s. It developed in the cities and in southeast Australian and women predominantly began to speak it.

Concerning the historical aspect of the development of Australian English it should be mentioned that there are a few theories. The most plausible is considered the "Sydney Mixing Bowl" theory explained by a high level of population mobility (Bernard 1969, Trudghill 1986). According to Bernard AusE began with the first generation of native-born Australians which was caused by the social situation in the colony. The "proto-Broad" accent of the new dialect is characterized by homogeneity and it was determined by the need of speech "upgrading" as later there was educational and economic development.

On the other hand Hammarstrom (1980) and Gunn (1992) claim that London English was brought to the colony and the speaker of other dialects quickly adapted to it. Horvarth mentions huge socio-economic differences in the colony, which explains linguistic variation from the beginning. Horvath also disagrees with Bernard`s explanation concerning the homogeneity of AusE because New South Wales and Tasmania were the colonies whereas Victoria, South Australia and Western Australia were not. Consequently it could not lead to the uniform linguistic features. According to Horvath the uniformity of AusE is explained by population mobility based on historical evidence.

In general AusE pronunciation is non-rhotic, intonation is flatter, speech rhythms are slow, stress is spaced more evenly, vowels are closer and more frontal than in RP.

\section{Phonology}

According to Peter Collins Alexander G. Mitchell and Arthur Delbridge were the first to research the phonology of AusE in 1940-60s. and they identified three varieties of AusE mentioned above: "Cultivated", "General" and "Broad" AusE. The use of Australian questioning intonation ("AQI") is popular in narrative texts to engage listeners and keep their attention.

\section{Morphology}

Hypocoristic suffixation with -ie (proper names for people, places, religions) and $-o$ (for men`s names an professional terms) is very common in AusE. Ther are also other examples of the suffixation.

\section{Grammar}

It is quite interesting that in AusE there is the trend to use Present Perfect Tense in the past tense context. Use of modal verbs is characterized by certain peculiarities: shall and ought to, the use of may instead of might in the expressions of past possibilities etc. another amazing feature of AusE is the use of but at the end of a sentence: e. g. He used to be a champion. He is a bit out of practice but. Yeah-no is another Australian "linguistic invention": he's a really good kid, he just comes over and we spoil him rotten. Yeahno he 's a good kid. This expression includes assent and dissent and enables speakers to compromise and maintain conversational solidarity [4].

\section{Canadian English}

Canada was inhabited by the Irish, Scottish and English in the $19^{\text {th }}$ century. There were English speakers earlier. When America's Thirteen Colonies started a war with Britain because of unpopular taxes a part of colonists were against it $(250,000)$, they were known as Loyalists as they remained loyal to the English Crown. They were oppressed in their civil rights and finally fled to other British Possessions. About 40,000 moved to British North America. Most of them settled in Eastern Canada where there were three provinces: New Brunswick, Nova Scotia and the Maritimes (Prince Edward Island). About 7000 Loyalists took up residence in Upper Canada (Ontario).

There was a great period of immigration from the British Isles between 1824 and 1860. In 1871 there were more than two million immigrants from the British Isles most of whom were the Irish.

In 1857 A. C. Geikie used the term Canadian English by which he described the English of Ontario and he considered it "a corrupt language". In 1889 W. D. Lighthall described the state of Canadian English mentioning that it was a uniform dialect with a small percentage of French words and crediting English, Scottish and Irish immigrants with their contribution into it. Ligthall also highlighted the resemblance of this dialect to American English (e. g. down town, pants, buggy, limbs, location) [5].

In general terms CanE is considered a mixture of $\mathrm{AmE}$ and BrE. It is caused by the contacts both with Great Britain (immigration) and the USA (commercial relations, mass media). 
There has been a debate since 1950s concerning the British and American elements in CanE. The debate was started by Matthew H. Scargill when he responded to Morton W. Bloomfield`s paper. Bloomfiel researched CanE and stated that there was a varied developmental model. Bloomfiel pointed at its historical development and adhered to the Loyalist Base History and proved it by the fact that CanE sounds more like AmE. On the other hand Scargill said that partially CanE looked like AmE but accents in BrE in $19^{\text {th }}$ centure were rhotic exactly like modern North American English. Since then all debates were focused on these two approaches [6].

Pronunciation in CanE. It should be mentioned CanE includes a larger use of British features. Conversely American English is acquiring the status of a prestige model and is becoming more common among younger upper layers of population in Cananda. It is regarded there is no standard Canadian pronunciation. Still the standard (general) Canadian English is the dialect spoken by educated middle-class Canadians living in cities from eastern border of Ontario to Vancouver Island. A survey made by Waler S. Avis in 1993 showed the variety among Ontario speakers in their pronunciation of many colloquial words. It is interesting that the influence of the French Language on CanE is very insignificant. The dialects of Maritimes (Nova Scotia, new Brunswick, prince Edward Isand), of Quebec (Montreal and the Eastern Township), and of the Ottawa Valley have slight difference from those in West (British Columbia), the Prairies (Alberta, Saskatchewan, and the Arctic North). The most distinguishing feature of CanE is rhoticity opposed to BrE which is non-rhotic. The ending -ing is pronounced in three ways: /in/, /in/ and /on/. The first way of pronunciation /in/ is more common in casual styles, /ən/ is not used frequently. Palatal glide (yod-form) $/ \mathrm{j} / \mathrm{after} / \mathrm{t} / \mathrm{l} / \mathrm{d} /$, or $/ \mathrm{n} /$ and before $/ \mathrm{u} /$ is preferred in CanE like in British English: duke/dju:k/, new /nju:/, tune/tju:n/. in AmE “yod-less" pronunciation is used: duke/du:k/, new /nu:/, tune /tu:n/ [5].

Canadian Raising and Canadian Shift are two very distinctive features of CanE. Canadian Rising is characterized by change in diphthongs in such words as mouth and price so the words with these two diphthongs are pronounced on a bit different way, e. g. house, mouse or wife, knife, price etc. It should be mentioned that effect of CR varies in different regions of Canada. The Canadian Shift affects front vowels in such words as kit, dress, trap etc. The vowels in the words kit $[\mathrm{I}]$, dress $[\varepsilon]$ are lowering and the vowel in the word trap [æ] is retracting [6].

Grammar. In CanE there are varieties in the use of prepositions: "on Blank Street" instead of "in Blank Street" (BrE), "first vacation in two years" instead of "first holiday for two years". Canadians use due to instead of owing to. The preposition to is preferred in an idiomatic expression (the influence of AmE): sick to the stomach instead of sick at the stomach. Other examples: name for instead of name after, wave at them - wave to them (BrE), all of the people (from $\mathrm{AmE}$ ) - all the people (BrE).

The expression 'cep'fer is a form of except for. Ever-exclamation has a strong emphatic meaning: Does he ever drive so fast! Any more has a positive meaning (southern Ontario): He complains lot any more. The phrase as well can be a sentence connector: She warned us of all the dangers. As well, she told us how to avoid them. The interjection eh is used in different types of sentences and has different meanings e. g. You like it eh?, You want to go, eh?, We had pizza, eh, and beer etc. The use of eh also relates to tags: isn't it?, does he?, haven't they? etc., which shows the tendency to the economy of language in CanE.

Vocabulary. C. J. Lovell's classification shows that CanE is a separate linguistic variety. According to Lovell CanE includes words of the following groups: changed everyday words (apartment block, bush pilot, staking rush etc.); words that are more often used in BrE (elevator instead of lift, movies (cinema), sidewalk (pavement) etc.); words that convey different meanings than in Br $\mathrm{E}$ (maid of honour, north country); words that have developed new meanings (reeve, frontier etc.).

Canadian vocabulary underwent the influence of both BrE and AmE. They say billboard (AmE) instead hoarding (BrE), porridge $(\mathrm{BrE})$ instead of oatmeal $(\mathrm{AmE})$, luggage $(\mathrm{BrE})$, not baggage $(\mathrm{AmE})$. But in the compound words baggage-car, baggagecheck American baggage is used. There are varieties both with store (AmE) and shop (BrE): barber shop, bake-shop, book-store, grocery-store, drug-store. There are also interchangeable word couples: braces (BrE) and suspenders (AmE), parcel and package, odd jobs and chores, a pack or a deck of cards. It should be mentioned that in political and legal terminology British English is dominant (cabinet, electoral district, cabinet etc.) while in the area of motoring and transport both British and American English is used: railway, trucks, fenders, cabooses - BrE; terms connected with trains (All aboard!!, conductor for guard, one-way ticket for single ticket etc.).

Canadianisms. There are Canadianisms from aboriginal languages: totem, toboggan, muskeg, pemmican (Alqonquian Indian), igloo, mukluk, kayak (Eskimo). Other examples of Canadianisms: hydro for hydro-electric, gridroad, cat train, chuck race, corduroy road, separate school, bank machine, washroom, snow shovel etc.

The impact of French on Canadian English. In 1969 Canada became a bilingual country. Montreal (Quebec) English underwent a huge influence of French but CanE was exposed to the impact of French in general.

There expressions derived from which are used only in English froms: mush (French Marche!), sny(e) (French chenail), lacrosse (French jeu de) la crosse, a name of Algonquian origin) unlike other words: carryall and cariole. Sush words as caboteur, coureur $d u$ bois, cache, voyageur, portage and seigniory relate to life, work and society in Canada.

Quebeck English. The word steamie is often used in Quebec English. It is suggested that this words originates from a Canadian French expression hot dog steamé. Poutine is French fries with cheese. Othe French words: autoroute for English highway, dépanneur from French dépanner (to repair), or one-and-a-half and two-and-a-half (one-room and two-room apartments respectively where half means a bathroom), stage for internship, chalet for summer cottage, guichet for ATM. The other examples are: collectivity (community in English), scholarity (schooling, from French scolarité), syndicate (a trade union from syndicat), reunion (meeting, from French réunion), "a good souvenir of something" (memory from French souvenir), deceive in the meaning of disappoint (French - décevoir).

The expressions take a decision (not make a decision), give a conference or give alecture (from French donner une conference) appeared under the impact of French. The verb to accept is used in such a structure: accept + infinitive (accept to call her) instead of accept + direct object (accept a conference).

Both Australian and Canadian English underwent a range of changes. These changes were incited by historic, social and linguistic aspects. AusE and CanE are characterized by a number of linguistic peculiarities the basis of which is British English [7]. 
Література:

1. Social Variation i Australian English. Olsjövägen 10.77270 Saxdalen. 2005. URL: http://www.diva-portal.se/smash/get/diva2:517801/ FULLTEXT01.pdf.

2. Aboriginal English: some gramatical features and their implications. Edith Cowan University. 2013. URL: https://benjamins.com/ catalog/aral.36.3.03mal/fulltext/aral.36.3.03mal.pdf.

3. Australian English. encyclopedia.com. 2020. URL: https://www.encyclopedia.com/humanities/encyclopedias-almanacs-transcriptsand-maps/australian-english.

4. Australian English: Its Evolution and Current State. University of New South Wales, Australia. 2012. URL: https://ejournals. epublishing.ekt.gr/index.php/latic/article/viewFile/2718/2487.

5. Canadian English. Charles University in Prague. 2010. URL: https://dspace.cuni.cz/bitstream/handle/20.500.11956/39668/BPTX 2 009_2_11410_0_84784_0_70456.pdf? sequence=1\&isAllowed=y.

6. Canadian English: a Conservative Variety. Zeitschrift fur Kanada-Studien. 2015. URL: http://www.kanada-studien.org/wp-content/ uploads/2015/03/zks_2015_2_Dollinger.pdf.

7. The English Language in Canada: a Questionable Dialect or a Distinct Variety of English. Masaryk University. 2006. URL: https:// is.muni.cz/th/t185d/Archiv-IS-Bc.pdf. 